\title{
Multiple Captures as an Indicator of Social Relations in the Wood Mouse and the Bank Vole
}

\author{
Ron VERHAGEN \& Walter N. VERHEYEN
}

\begin{abstract}
Verhagen R. \& Verheyen W. N., 1982: Multiple captures as an indicator of social relations in the wood mouse and the bank vole. Acta theriol., 27, 17: 231-241 [With 6 Tables]

Behavioral interactions in Apodemus sylvaticus (Linnaeus, 1758) and Clethrionomys glareclus (Schreber, 1780) were studied by the analysis of multiple captures of individuals in Sherman traps. The frequency of occurrence of multiple captures in relation to the total number of animals caught was very different depending on the species involved. In insectivores it proved to be an exceptional event while in A. sylvaticus and C. glareolus it was more common. Occasions in which two individuals of different species were caught together occurred very seldom. In both species, sexually inactive animals were more involved in multiple captures than sexually active animals. It was seer that juveniles were caught significantly more together than any other possible combination, whereas combinations where both animals were sexually active were not as common as expected. Multiple captures with both adult animals were more common in winter than in summer and if they occurred in summer, nearly all were malefemale multiple captures.

[Laboratorium voor Algemene Dierkunde, R.U.C.A., Groenenborgerlaan 171, University of Antwerp, 2000 Antwerp, Belgium]
\end{abstract}

\section{INTRODUCTION}

Many investigations indicate that intraspecific relations between individuals of populations of the wood mouse, Apodemus sylvaticus (Linnaeus, 1758), and the bank vole, Clethrionomys glareolus (Schreber, 1780), can play an essential role in the dynamics and the structure of their populations (Watts, 1969 ; Bujalska, 1970, 1971 ; Flowerdew, 1974 ; Flowerdew \& Gardner, 1978; Gurnell, 1978; Gipps \& Jewell, 1979; Green, 1979). However, data from field observations are very difficult to obtain and therefore scanty.

Analysis of multiple captures can provide some information on the kind of relations that exist between individuals and how the frequency of occurrence changes with time. Depending on the trap type used one can recognize two different kinds of multiple captures. First, there are traps which allow several animals to be caught during a trapping session (Bergstedt, 1965; Kalinowska, 1971). Because, in most cases,

[231] 
the animals do not enter the trap simultaneously this type of trap is very effective to investigate the effect that a captured animal exerts on the capture of a second individual. On the other hand, when using traps with a single entrance, for example a Sherman or a Longworth trap, the situation is different. Indeed, if a multiple capture of two or more animals in such a trap has to occur, the individuals must enter the trap side by side which probably supposes a high degree of social tolerance. Therefore, through the analysis of multiple captures we can gain some insight in the behavioral relations between members of the population.

\section{MATERIAL AND METHODS}

In the present article we will discuss the data of multiple captures in Sherman traps colleqted from May 1976 to $\mathbb{N}$ November 1980 in a study area at Dongen, Belgium. Details of the study area can be found in Verhagen (1980).

The basic field technique was regular live trapping with collapsible aluminium Sherman traps $(76 \times 89 \times 229 \mathrm{~mm})$. Trapping sessions of mostly three nights were undertaken at regular intervals. In the first two years of this study the interval between trapping sessions was two weeks, after March 1978 trapping sessions were spaced three or four weeks apart.

All grids had trapping stations set $15 \mathrm{~m}$ apart and at each station two traps were placed and baited with peanut butter. The catch was examined three times a day (sunrise, afternoon and around midnight).

Nnewly captured wood mice and bank voles were marked by toe-clipping and released after the necessary data were recorded. Each animal was weighed to the nearest gram and sex and reproductive condition were noted. Females were considered as sexually active if they had a perforate vagina, were lactating or pregnant and males if the testes were descended. The age of newly captured animals was determined in the way described by Verhagen (1980) and Verhagen \& Vandorpe (1979).

All insectivore and most Microtus-species were removed after their initial capture.

\section{RESULTS}

\subsection{Occurence of Multiple Captures}

All data presented in table 1 were multiple captures of individuals of the same species. Only twice we caught two different species in the same trap. On the first occasion an A. sylvaticus (juvenile male) was trapped together with a $C$. glareolus (adult male); here A. sylvaticus was dead and partly eaten by $C$. glareolus. On the second occasion an A. sylvaticus and a Sorex araneus (Linnaeus, 1758) were found together, both in good health. 
So it seems that multiple captures where two different species are involved are indeed rare and may even be considered as exceptional. Single-species multiple captures occur at low frequencies but the phenomenon seems to be very different depending on the species involved (Table 1). In insectivores it seems to be a very rare event which happened only once in 1915 captures (equal to $0.05 \%$ ). In A. sylvaticus and C. glareolus multiple captures are much more common that in insectivores. On the other hand there are significantly more multiple captures for A. sylvaticus than for C. glareolus $\left(\chi^{2}=4.50, p<0.05\right)$.

Table 1

Number of multiple captures recorded for the different species caught in the study area.

\begin{tabular}{lccc}
\hline \multicolumn{1}{c}{ Species } & $\begin{array}{c}\text { Total number } \\
\text { captures }\end{array}$ & $\begin{array}{c}\text { Number of multiple } \\
\text { captures }\end{array}$ & $\%$ \\
\hline Apodemus sylvaticus & 11.931 & 72 & 0.60 \\
Clethrionomys glareolus & 8.509 & 33 & 0.39 \\
Sorex araneus & 1.093 & 0 & 0.00 \\
Sorex minutus & 718 & 1 & 0.00 \\
Crocidura russula & 104 & 0 & \\
\hline
\end{tabular}

Four times, one of the captured animals was found dead in the trap. In three occasions the dead was caused by strangling because the animal was trapped between the roof and the closed door of the trap but in the fourth occasion, an $A$. sylvaticus multiple capture of two subadults, one animal was found dead and partly eaten by the other. It was not clear if the dead of one of the animals was the result of aggressive interactions or had an other cause. In all the other cases the animals were in good condition and there were no visible signs that could be the result of aggressive behaviour.

Three times, we recorded an A. sylvaticus multiple capture in which we found three mice in one trap. Twice, an adult female, with signs of recent lactation, was trapped with two juveniles and once an adult sexually active male was caught together with two juveniles. This phenemenon was never recorded for C. glareolus.

We will now analyse the data for these two species more in detail.

\subsection{Differences Between Groups}

To test if there is any difference between sexually active and inactive animals and between the sexes, we calculated the excepted number of 
animals involved in multiple captures from the total number of captures registred in each group and compared these values with the observed numbers (Table 2).

Table 2

Number of animals involved in multiple captures divided in sex and sexual activity classes for $A$. sylvaticus and $C$. glareolus. The number of captures in each class is placed between parentheses.

\begin{tabular}{|c|c|c|c|}
\hline Species & Sexually active & Sexually inact. & $\chi^{2}$ \\
\hline $\begin{array}{l}\text { A. sylvaticus } \\
\text { males }\end{array}$ & $28 \quad(4049)$ & $41 \quad(2180)$ & $18.09, p<0.001$ \\
\hline females & $19 \quad(2634)$ & $56 \quad(3068)$ & $13.14, p<0.001$ \\
\hline$\chi^{2}$ between sexes & 0.03 N.S. & 0.02 N.S. & \\
\hline $\begin{array}{l}\text { C. glareolus } \\
\text { males }\end{array}$ & $(2755)$ & (2122) & $15.10, p<0.001$ \\
\hline females & $2 \quad(1696)$ & $25 \quad(1936)$ & $16.75, p<0.001$ \\
\hline$\chi^{2}$ between sexes & 2.33 N.S. & 0.04 N.S. & \\
\hline
\end{tabular}

There are many more sexually inactive animals involved in multiple captures than sexually active animals. These differences are statistically significant for both sexes and species. Despite the fact that multiple captures for sexually active females of $C$. glareaolus are very few, the differences between the sexes are not significant.

\subsection{Analyses of Combinations}

When we recognize three groups of animals, namely sexually active males, sexually active females and sexually inactive males and females, we can distinguish 6 possible combinations of these groups which can occur in multiple captures (Table 3). The expected frequencies for the combinations were derived from the total number of captures in each group.

For both species the combination in which only sexually inactive animals are involved occurs significantly more than expected and also more than all the other combinations. In A. sylvaticus the capture of two sexually active animals, especially males, in the same trap is observed significantly less frequently than expected which, however, is not the case for $\boldsymbol{C}$. glareolus. Another marked difference between these two species is that in multiple captures where sexually active and inactive A. sylvaticus were found together, we can find no statistically significant difference between the observed and expected values, whereas in C. glareolus the diference is highly significant. 
In the previous analysis we did not take into account the age of the individuals and a sexually inactive animal could be as well a juvenile as an adult animal. Therefore we will not distinguish three groups where no difference between sexes is made, namely, sexually active animals aged more than two months, sexually inactive animals of the

Table 3

for each group as well as the observed (obs.) and expected (exp.) frequencies are Prevalence of different combinations in multiple captures. The number of captures tabulated.

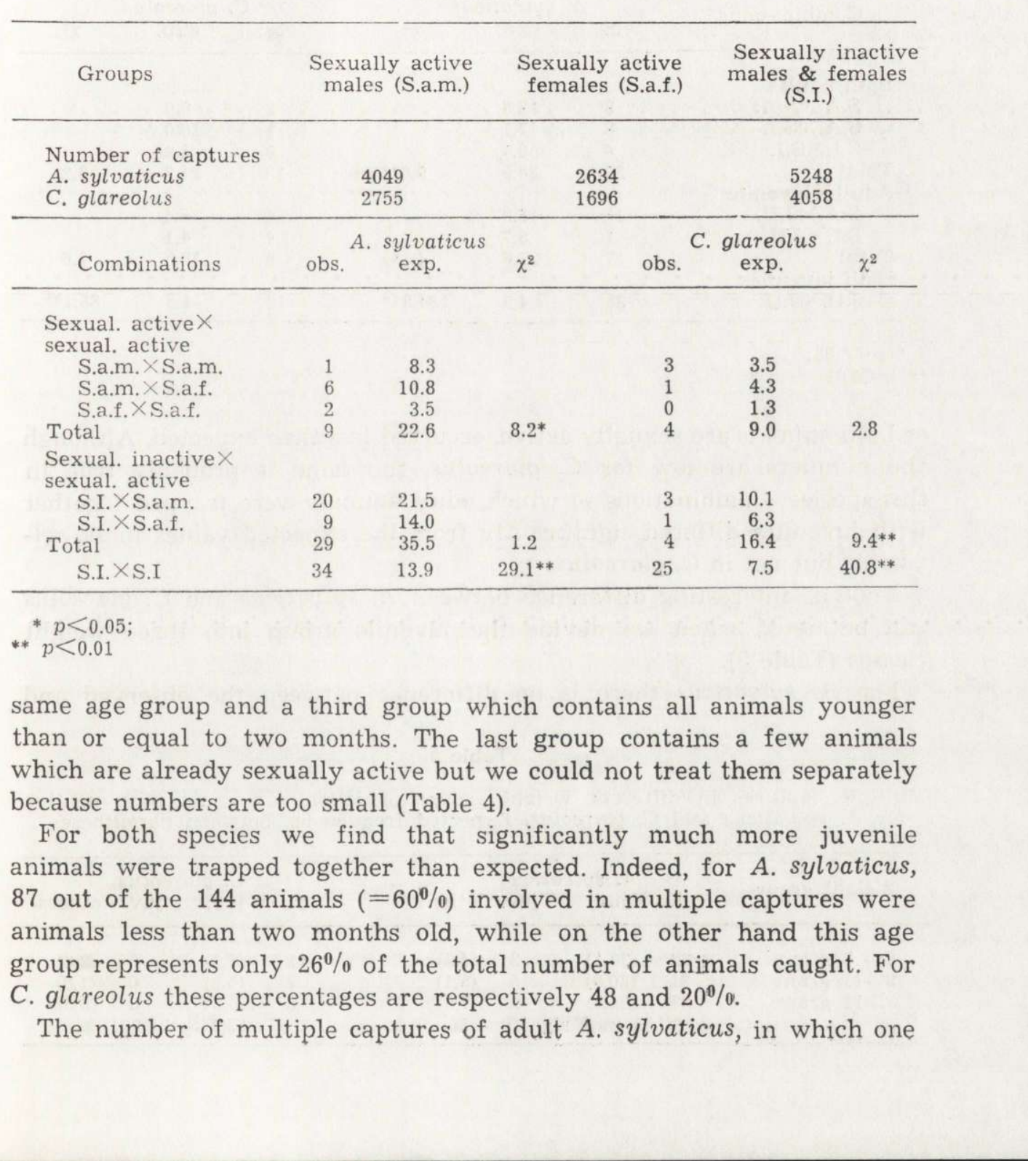


Table 4

Analysis of combinations to test whether there are differences in multiple captures between age-groups.

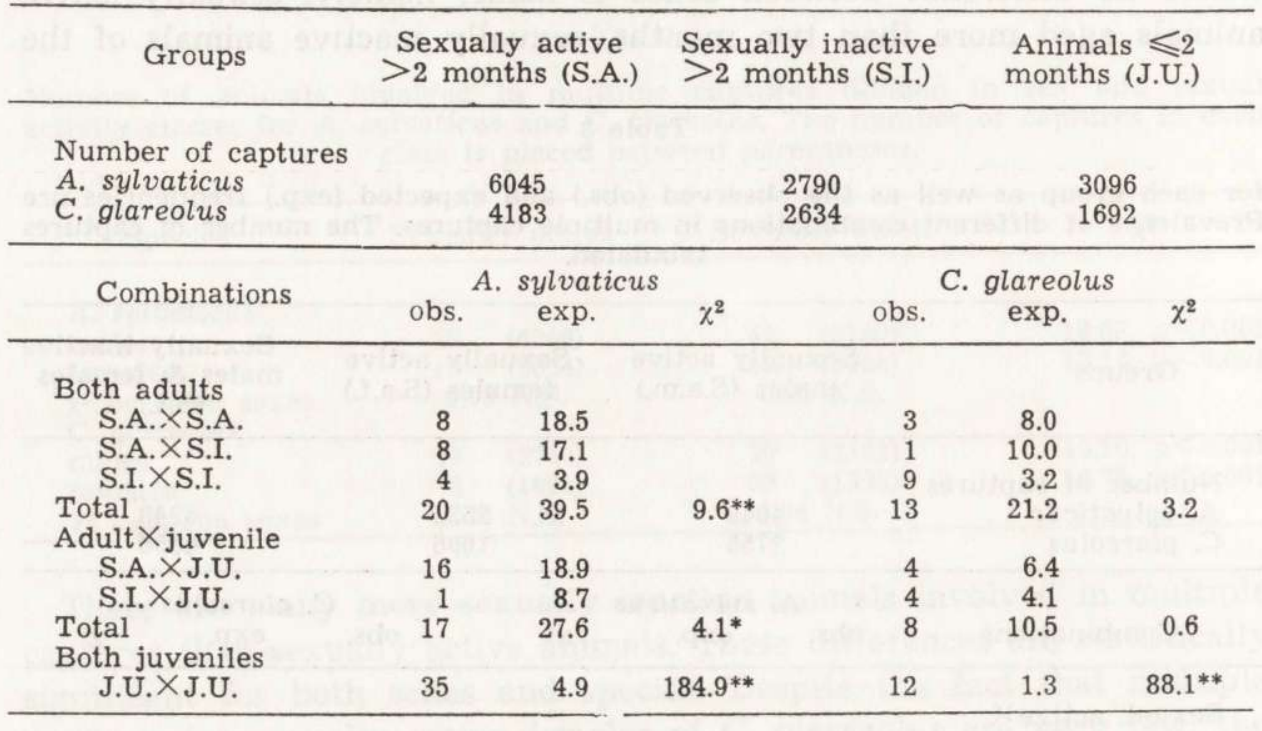

$* p<0.05$

** $p<0.01$

or both animals are sexually active, occurred less then expected. Although the numbers are low for C. glareolus, the same is probably true in this species. Combinations in which adult animals were trapped together with juveniles differed significantly from the expected values in A. sylvaticus but not in C. glareolus.

Another interesting difference between A. sylvaticus and C. glareolus can be noted when we devide the juvenile group into three weight classes (Table 5).

For A. sylvaticus there is no difference between the observed and

Table 5

Multiple captures in different weight groups of juvenile animals ( $\leqslant 2$ months) for $A$. sylvaticus and $C$. glareolus. Expected frequencies between parentheses.

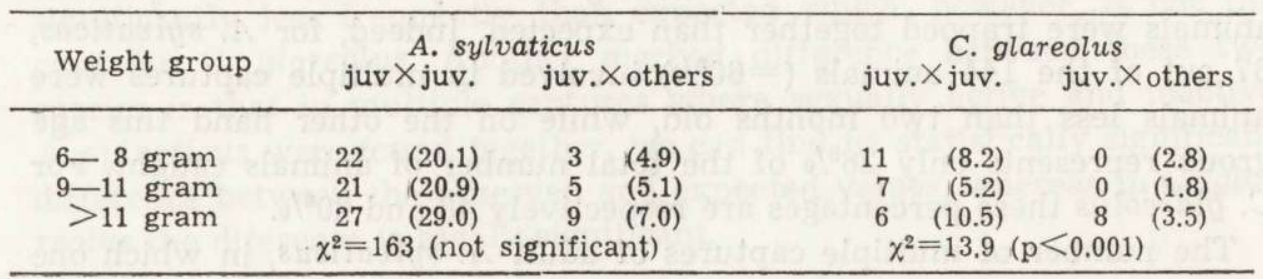


expected number of juveniles captured with other juveniles or with older animals whereas there is a significant difference in C. glareolus. In the latter no juvenile animals of the two lower weight classes are found together with older animals.

\subsection{Seasonal Differences in Multiple Captures}

To examine whether there are seasonal differences in the number of multiple captures, the data are split up into two periods: springsummer (March-August) and autumn-winter (September-February).

The expected frequencies for the different combinations in winter and summer are calculated for each combination in the following way. Let n.obs. be the total number of observed multiple captures for a particular combination $X \times Y$ and $x_{s}, y_{s}$ and $x_{w}, y_{w}$ the total number of captures for group $X$ and $Y$ in summer, respectively winter, then the expected frequency for the number of multiple captures for a particular combination in summer is :

$$
\begin{gathered}
\mathrm{X} \cdot \mathrm{Y} \exp (\mathrm{s})=\text { n.obs. }\left[\frac{x_{s} \cdot y_{s}}{\left(x_{s}+y_{s}+x_{w}+y_{w}\right)^{2}}\right] \times\left[\frac{x_{s} \cdot y_{s}}{\left(x_{s}+y_{s}+x_{w}+y_{w}\right)^{2}}+\right. \\
\left.+\frac{x_{w} \cdot y_{w}}{\left(x_{s}+y_{s}+x_{w}+y_{w}\right)^{2}}\right]^{-1}=\text { n.obs. }\left\lfloor\frac{x_{s} \cdot y_{s}}{\left(x_{s} \cdot y_{s}\right)+\left(x_{w} \cdot y_{w}\right)}\right]
\end{gathered}
$$

The expected frequency for the winter can be calculated in a similar way.

Seasonal differences in the number of multiple captures exist in those combinations wherein adult animals of the same sex are captured together (Table 6). The number of these combinations occur less frequently then expected in the summer period and differences are statistically significant for both species. In combinations of adult animals of opposite sex, however, there seems to be no seasonal difference.

For A. sylvaticus there are no statistical significant differences between seasons for the other possible combinations and for the total number of multiple captures but in C. glareolus we see that for combinations in which juveniles and adults are found together, that the number of these multiple captures in summer is less than expected. This is also true when we compare the total number of multiple captures in winter and summer for this species.

\section{DISCUSSION}

Many authors have mentioned that there is a tendency for interspecific avoidance in rodents. This was demonstrated with the use of multiple capture traps (Bergstedt, 1965; Kalinowska, 1971), the study 


\section{Table 6}

Seasonal differences of multiple captures for A. sylvaticus and C. glareolus.

\begin{tabular}{|c|c|c|c|c|}
\hline & Summer & \multicolumn{2}{|c|}{ Winter } & \\
\hline $\begin{array}{ll}\text { A. sylvaticus-captures } & \\
\text { males and females } & \leqslant 2 \text { months (JU) } \\
\text { females } & >2 \text { months (AF) } \\
\text { males } & >2 \text { months(AM) }\end{array}$ & $\begin{array}{l}1938 \\
2518 \\
2482\end{array}$ & \multicolumn{2}{|c|}{$\begin{array}{l}1158 \\
1708 \\
2127\end{array}$} & \\
\hline Combinations & obs. exp. & obs. & exp. & $\chi^{2}$ \\
\hline $\begin{array}{l}\mathrm{JU} \times \mathrm{JU} \\
\mathrm{JU} \times \mathrm{AF} \\
\mathrm{JU} \times \mathrm{AM} \\
\mathrm{AF} \times \mathrm{AF} \\
\mathrm{AM} \times \mathrm{AM} \\
\mathrm{AF} \times \mathrm{AM}\end{array}$ & $\begin{array}{rr}27 & 25.8 \\
7 & 6.4 \\
7 & 5.3 \\
1 & 2.0 \\
0 & 4.0 \\
5 & 6.3 \\
\end{array}$ & $\begin{array}{l}8 \\
2 \\
1 \\
2 \\
7 \\
5 \\
\end{array}$ & $\left.\begin{array}{l}9.2 \\
2.6 \\
2.7 \\
1.0 \\
3.0 \\
3.7\end{array}\right\}$ & $\begin{array}{c}0.21 \\
1.45 \\
10.42^{* *} \\
0.73\end{array}$ \\
\hline Total & $47 \quad 49.8$ & 25 & 22.2 & 0.51 \\
\hline \multicolumn{5}{|c|}{$\begin{array}{llrr}\text { C. glareolus-captures } & & & \\
\text { males and females } & \leqslant 2 \text { months (JU) } & 953 & 597 \\
\text { females } & >2 \text { months (AF) } & 1739 & 1089 \\
\text { males } & >2 \text { months (AM) } & 2639 & 1492\end{array}$} \\
\hline Combinations & obs. exp. & obs. & exp. & $\chi^{2}$ \\
\hline $\begin{array}{l}\mathrm{JU} \times \mathrm{JU} \\
\mathrm{AF} \times \mathrm{AF} \\
\mathrm{JU} \times \mathrm{AM} \\
\mathrm{JU} \times \mathrm{AF} \\
\mathrm{AM} \times \mathrm{AM} \\
\mathrm{AF} \times \mathrm{AM}\end{array}$ & $\begin{array}{ll}8 & 8.6 \\
0 & 1.4 \\
3 & 4.4 \\
0 & 1.4 \\
1 & 4.5 \\
4 & 3.7 \\
\end{array}$ & $\begin{array}{l}4 \\
2 \\
3 \\
2 \\
5 \\
1 \\
\end{array}$ & $\left.\begin{array}{l}3.4 \\
0.6 \\
1.6 \\
0.6 \\
1.5 \\
1.3\end{array}\right\}$ & $\begin{array}{c}0.15 \\
4.92^{*} \\
15.50^{* *} \\
0.09\end{array}$ \\
\hline 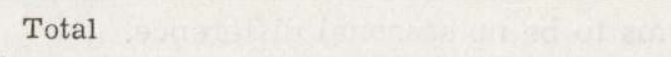 & $16 \quad 24.0$ & 17 & 9.0 & $9.78^{* *}$ \\
\hline \multicolumn{5}{|c|}{$\begin{array}{l}\text { * } p<0.05 \text {; } \\
\text { ** } p<0.01 \\
\text { of activity patterns (Brown, } 1956 \text {; Bergstedt, } 1965 \text {; Greenwood, 1978) } \\
\text { and by direct visual observation in the field (Andrzejewski \& Olszewski, } \\
1963 \text {; Kikkawa, 1964). Montgomery (1979) who analyzed } 65 \text { multiple } \\
\text { captures of A. sylvaticus, A. flavicollis and C. glareolus found a strong } \\
\text { bias towards single species multiple captures and he stated that it is } \\
\text { likely that individuals only recognize other individuals of their own } \\
\text { species. Our results confirm that individuals of a particular species seem } \\
\text { to associate nearly only with others of their own species rather than } \\
\text { with individuals of other species. }\end{array}$} \\
\hline
\end{tabular}


Beside this interspecific avoidance it is clear that the social tolerance between individuals of the same species differs strongly from species to species. In insectivores, like Sorex araneus and $S$. minutus, which are likely to be territorial (Croin Michielsen, 1966) multiple captures proved to be a very rare event whereas in rodents like $A$. sylvaticus and C. glareolus multiple captures are more common. Many authors suggested that there exist social relations between individuals in $C$. glareolus or in A. sylvaticus of which the intensity is dependent on factors as sex, age, weight, breeding conditions and season (Kołodziej et al., 1972 ; Bujalska, 1973 ; Garson, 1975 ; Randolph, 1977 ; e.a.).

The very high frequency of juvenile-juvenile multiple captures in A. sylvaticus suggests that social relations are especially strong in juvenile animals (Table 4). When two juveniles are trapped together they often have the same weight so it is likely that they are nestlings. We suppose that when weanlings leave their nest, they stay in close proximity with each other when exploring the surroundings of the nest site. It is however probable that when the animals get older but have not yet established a home range, close contacts with individuals of other nests are likely to occur.

In his study on Peromyscus, Howard (1948) mentioned that the young remain in the home range of the parent and may travel as a group of littermates or with the parents. That a similar situation probably also exists in A. sylvaticus, is supported by the fact that we recorded three multiple captures in which two juveniles were trapped together with an adult animal. In these three occasions, all juveniles were very young animals and had the same weight. In one case an adult female was captured again with one of these juveniles.

The close contact between juveniles and adults seems not to exist in C. glareolus. Indeed, we never trapped a sexually active adult together with a juvenile and in the cases of multiple captures of juveniles with adult males, the juveniles were always much older than what we found for A. sylvaticus (see Table 5).

Multiple captures of adult animals are much more common in winter than in summer and when occuring in summer nearly all were malefemale multiple captures. This observation supports the belief that adults of the same sex in A. sylvaticus are in some way territorial during the breeding season and form bisexual spatial associations while in the winter period the tolerance between individuals of the same sex is better and that they even could form monosexual aggregations (Watts, 1969 ; Randolph, 1977; Gurnell, 1978). The same is probably true for C. glareolus, 
Acknowledgements: I wish to acknowledge the Ministry of Agriculture for permission to work in Dongen Wood. The work is supported by a grant from the National Fund for Scientific Research (Belgium).

\section{REFERENCES}

1. Andrzejewski R. \& Olszewski J., 1963: Social behaviour and interspecific relations in Apodemus flavicollis and Clethrionomys glareolus. Acta theriol., 7: $155-168$

2. Bergstedt B., 1965: Distribution, reproduction, growth and dynamics of the rodent species Clethrionomys glareolus (Schreber), Apodemus flavicollis (Melchior) and Apodemus sylvaticus (Linné) in southern Sweden. Oikos, 16: 132160 .

3. Brown L. E., 1956: Field experiments on the activity of the small mammals Apodemus, Clethrionomys and Microtus. Proc. zool. Soc. Lond., 126: 549-564.

4. Bujalska G., 1970: Reproduction stabilizing elements in an island population of Ciethrionomys glareolus (Schreber, 1780). Acta theriol., 15: 381-412.

5. Bujalska G., 1971: Self-regulation of reproduction in an island population of Clethrionomys glareolus (Schreber, 1780). Ann. Zool. Fenn., 8: 91-93.

6. Bujalska G., 1973: The role of spacing behaviour among females in the regulation of reproduction in the bank vole. J. Reprod. Fert., Suppl. 19: 463-472.

7. Croin Michielsen N., 1966: Intraspecific and interspecific competition in the shrews Sorex araneus L. and S. minutus L. Arch. néerl. Zool., 17: 73-174.

8. Flowerdew J. R., 1974: Field and laboratory experiments on the social behaviour and population dynamics of the wood mouse (Apodemus sylvaticus). J. Anim. Ecol., 43: 499-511.

9. Flowerdew J. R. \& Gardner G., 1978: Small rodent populations and food supply in a Derbyshire ashwood. J. Anim. Ecol., 47: 725-740.

10. Garson P. S., 1975: Social interactions of Woodmice (Apodemus sylvaticus) studied by direct observation in the wild. J. Zool., Lond., 177: 496-500.

11. Gipps J. H. W. \& Jevell P. A., 1979: Maintaining populations of bank voles, Clethrionomys glareolus, in large outdoor enclosures, and measuring the response of population variables to the castration of males. J. Anim. Ecol., 48: 535-555.

12. Green R., 1979: The ecology of Wood mice (Apodemus sylvaticus) on arable farmland. J. Zool. Lond., 188: 357-377.

13. Greenwood P. J., 1978: Timing of activity of the bank vole Clethrionomys glareolus and the wood mouse Apodemus sylvaticus in a deciduous woodland. Oikos, 31: 123-127.

14. Gurnell J., 1978: Seasonal changes in numbers and male behavioural interaction in a population of wood mice, Apodemus sylvaticus. J. Anim. Ecol., 47: 741-755.

15. Howard W. E., 1948: Dispersal, amount of inbreeding, and longevity in a local population of prairie deer-mice on the George Reserve, southern Michigan. Contr. Lab. Vert. Biol. Univ. Mich., 43: 1-50.

16. Kalinowska A., 1971: Trapping of Apodemus flavicollis and Clethrionomys glareolus into a double trap. Acta theriol., 16: 73-78.

17. Kikkawa J., 1964: Movement, activity and distribution of the small rodents Clethrionomys glareolus and Apodemus sylvaticus in woodland. J. Anim. Ecol., 33: 259-299. 
18. Kołodziej A. \& Pomianowska I., Rajska E., 1972: Differentiation of contacts between specimens in a Clethrionomys glareolus population. Bull. Acad. Pol. Sci., 20: 97-102.

19. Montgomery W. I., 1979: Multiple captures in Longworth traps. J. Zool., Lond., 188: 286-288.

20. Randolph S. E., 1977: Changing spatial relationships in a population of Apodemus sylvaticus with the onset of breeding. J. Anim. Ecol., 46: 653-676.

21. Verhagen R. \& Vandorpe E., 1979: A method for age determination of rodents in the field, illustrated by growth of the Wood mouse, Apodemus sylvaticus (Linnaeus, 1758). Ann. Soc. r. Zool. Belg., 109: 127-132.

22. Verhagen R., 1980: A population dynamic study of the Wood mouse, Apodemus sylvaticus (Linnaeus, 1758) and the Bank vole, Clethrionomys glareolus (Schreber, 1780) in different habitats of the northern Kempen. Ph. D. Thesis. Department of Biology, University of Antwerp, Antwerp. Pp. 1-351.

23. Watts C. H. S., 1969: The regulation of wood mouse (Apodemus sylvaticus) numbers in Wytham Woods. Berkshire. J. Anim. Ecol., 38: 285-304.

Accepted, December 15, 1981.

RON VERHAGEN i Walter VERHEYEN

WIELOKROTNE ZŁOWIENIA JAKO WSKAŻNIK STOSUNKOW SOCJALNYCH U MYSZY ZAROSLOWEJ I NORNICY RUDEJ

Streszczenie

Badano zależności behawioralne u Apodemus sylvaticus (Linnaeus, 1758) i Clethrionomys glareolus (Schreber, 1780), wykorzystując dane uzyskane $\mathrm{z}$ analizy wielokrotnych złowień osobników tych gatunków w pułapki Shermana. Odłowy prowadzono od maja 1976 do listopada 1980 r., w okolicach Dongen w Belgii. Pułapki na powierzchni odłownej ustawiano co $15 \mathrm{~m}$, po dwie w punkcie łownym i kontrolowano je trzy razy dziennie. Odłowione zwierzęta znakowano przez obcięcie palca, ważono, określano płeć i aktywność płciową a także wiek. Częstotliwość występowania wielokrotnych złowień w stosunku do ogólnej liczby złowionych zwierząt była bardzo różna, zależnie od gatunku (Tabela 1). U Insectivora takie złowienia były zjawiskiem zupełnie wyjątkowym, podczas gdy $\mathrm{u} A$. sylvaticus i C. glareolus czymś całkiem pospolitym. Przypadki, w których 2 osobniki różnych gatunków złowiły się razem są bardzo rzadkie. U obu badanych gatunków, nieaktywne płciowo osobniki były łowione wielokrotnie częściej niż aktywne (Tabela 2 i 3). Zauważono też, że osobniki młode łowiły się istotnie częściej razem, niż inne możliwe kombinacje, podczas gdy układy w których oba zwierzęta były aktywne płciowo nie były tak pospolite jak oczekiwano (Tabela 4,5 i 6 ). 